\title{
Religion and Politics in Postcommunist Russia*
}

\author{
STEPHEN WHITE, IAN MCALLISTER and OL'GA KRYSHTANOVSKAYA
}

The end of communist rule and of the USSR itself brought an end to the restrictions upon freedom of worship with which Russian religious believers had previously been obliged to contend. ${ }^{1}$ There had certainly been significant changes in the position of believers and their churches in the late communist period. Mikhail Gorbachev, it emerged, had himself been baptised; his mother was a regular worshipper. ${ }^{2}$ An early gesture of some importance was the return of the Danilov monastery in Moscow to the Orthodox Church; refurbished, it played a central role in the millennium of the Orthodox Church in 1988, which brought church and state more closely together than at any time in the recent past. Speaking at this time the patriarch described the communist party programme as 'highly humane' and 'close to the Christian ideal'; Gorbachev himself met the patriarch during the celebrations and noted that church and state shared a 'common interest' in protecting public morality. ${ }^{4}$ In December 1989 Gorbachev had met the pope, in what was the first encounter of its kind; the following year diplomatic relations were formally established with the Holy See. ${ }^{5}$ In 1990 the Communist Party adopted a new set of rules allowing religious believers to join its ranks. Believers, even priests, began to appear in the press and electronic media; the first religious leaders were elected to the Soviet parliament in 1989; a weekly religious newspaper was launched; and a religious presence began to establish itself in charitable and educational work.

The last months of communist rule, in 1990 and 1991, extended the liberties of believers through a series of more formal measures. The Law on Property, approved in 1990 , gave the churches full rights of ownership, ${ }^{6}$ and a Law on Freedom of Conscience and Religious Organisations, adopted later in the year, affirmed the right of believers to practise and of parents to give their children a religious upbringing. The churches, for their part, had the right to participate in public life and establish their own media outlets, although not to establish or finance their own political parties; and they had the right to establish their own schools and higher educational institutions, and to produce and sell their own literature. ${ }^{7}$ The USSR parliament, in one of its last acts, adopted a Declaration of the Rights and Freedoms of the Individual which guaranteed freedom of religious belief and practice, including the right to evangelise and to conduct religious education. ${ }^{8}$ The Russian parliament, meeting in November 1991, adoted a more specific set of 'rights and freedoms of the individual and citizen', and in April 1992 they were incorporated into the Russian constitution. The

*Stephen White and Ol'ga Kryshtanovskaya gratefully acknowledge the financial support of the ESRC. 
amendments made clear that the rights and freedoms of the individual were of the 'highest value' in postcommunist Russia, and that the practice or propagation of a religion was an inalienable human right. ${ }^{9}$

Acting within the framework of this legislation, religious groups and believers more generally had come to play a central role in Russian public life in the early 1990s. The patriarch was involved in official ceremonies of state, including the inauguration of the newly elected Russian president in July $1991 .^{10}$ There were several religious parties, including the Christian Patriotic Union (founded in 1988), the Christian Democratic Union of Russia (founded in 1989), and the People's Orthodox Movement of Russia, the Russian Christian Democratic Party and the Russian Christian Democratic Movement, all of them founded in 1990. ${ }^{11}$ New churches and monasteries were opened; the first services took place in Kremlin cathedrals; the Orthodox Christmas became a public holiday; and the first religious broadcasts went out over state television. ${ }^{12}$ By the early 1990s, religious believers had clearly escaped from the marginalisation and even repression of the Soviet period; yet their views were imperfectly articulated by religious parties or the church hierarchies, and there was little satisfactory information about the distribution of religiosity or its association with the policy agenda of a postcommunist system. In this paper we examine both of these issues, using two Russia-wide opinion surveys that were conducted in 1992 (for further details see the Appendix).

\section{Religious Affiliation and Belief in Postcommunist Russia}

The evidence certainly suggested that, at least in the early postcommunist years, religion and the churches were held in high public esteem. In a Russia-wide urban survey conducted in early 1992, for example, respondents were asked what feelings were evoked by the word 'Christianity'. As Table 1 shows, for 73 per cent, their response was a positive one; 24 per cent found it difficult to say; and only 3 per cent had a negative reaction. By contrast, 45 per cent were hostile to perestroika, 37 per cent to Marxism-Leninism and 33 per cent to socialism; a further 28 per cent were opposed to capitalism and 16 per cent to glasnost'. Overall, judged by the number of positive responses relative to negatives ones, Christianity ranked behind only 'freedom' and an

Table 1. Public opinion on popular symbols

\begin{tabular}{|c|c|c|c|c|c|c|}
\hline & & $\begin{array}{c}\text { (Positive } \\
\text { minus } \\
\text { negative) }\end{array}$ & Positive & Undecided & Negative & Total \\
\hline 1 & Freedom & +73 & 78 & 17 & 5 & 100 \\
\hline 2 & Indivisible Russia & +70 & 75 & 20 & 5 & 100 \\
\hline 3 & Christianity & +49 & 73 & 3 & 24 & 100 \\
\hline 4 & Glasnost' & +47 & 63 & 21 & 16 & 100 \\
\hline 5 & Capitalism & -3 & 25 & 47 & 28 & 100 \\
\hline 6 & Socialism & -8 & 25 & 42 & 33 & 100 \\
\hline 7 & Marxism-Leninism & -21 & 16 & 46 & 37 & 99 \\
\hline 8 & Perestroika & -25 & 21 & 33 & 46 & 100 \\
\hline
\end{tabular}

a The question was 'We often hear the following words. What feelings do they evoke?' Figures may not sum to 100 due to rounding. A small number of respondents who did not answer the question are excluded.

Source: December 1992 Political Parties of Russia Survey $(n=1,509)$. 
'indivisible Russia'. Positive attitudes towards Christianity, moreover, were distributed evenly across all age groups, genders and regions, and even (though less strikingly) across political persuasions. Those who still regarded themselves as communist party members were almost as favourable to Christianity as they were to socialism (53 per cent were positive, 8 per cent negative); former CPSU members - a very much larger group - were more positive still (71 per cent were favourable towards Christianity and just 5 per cent were hostile). ${ }^{13}$

A broadly positive pattern of responses appeared to reflect a substantial change in public attitudes in the late 1980 s. Under Brezhnev, as a recent study has pointed out, ${ }^{14}$ religion had become fashionable among intellectuals in large cities and among the creative intelligentsia more generally. But the scale of this process was small, and the polls conducted at the time 'did not show any growth of religious sentiments'. In 1988, for instance, a joint US-Soviet investigation in Moscow suggested that only about 10 per cent of the population believed in God. Between 1988 and 1990, however, the process developed 'at the speed of an avalanche'. According to surveys conducted in 1990, up to 27 per cent of Moscow's population were believers, as compared with 20 per cent who were atheists; the proportions of believers and of atheists were higher in other urban areas, but believers were also more numerous ( 29 per cent compared with 26 per cent of atheists). By 1991 the proportion of atheists was down in Moscow to 10 per cent, and in other cities to 14 per cent. All of this, for Filatov and Furman, was evidence of a swing of the 'religious pendulum': oriented towards atheism for a long time (from the 1930s to the 1960s), it began a 'slow and barely perceptible' movement towards religion in the 1970 s, gained momentum, and 'finally assumed great speed in 1988-1990'. ${ }^{15}$

By 1991, according to surveys in several urban areas, religious belief was strongest among the young and the old, with 39 per cent of those aged over 60 reporting a 'belief in God'. No more than 17 per cent of any age group, however, were convinced atheists, and many more (up to 36 per cent for those aged 51-60) were at least agnostic. In the past, atheism had been inculcated by the more educated and then absorbed by workers. In the late communist years almost exactly the reverse was true: there were fewer believers among those with a higher education than among members of other educational groups, but their interest in religion was greater and they went to church more often. Levels of religiosity were especially high among the cultural intelligentsia (44 per cent believed in God), relatively high among doctors ( 35 per cent) and teachers (23 per cent), but lower among engineers (16 per cent). There was a certain 'symmetry' in a geographical sense as well, as Moscow and St Petersburg, where the movement towards atheism had begun in the 1920s, were now among the areas with the highest levels of reported religious belief. ${ }^{16}$

There was a still broader welcome to the idea that religious beliefs should play a greater role in Russian or Soviet society. In October 1991, for instance, a Russia-wide survey found that 64 per cent thought the wider diffusion of religious beliefs would be of benefit to the society, and only 6 per cent thought it would be harmful (just two years earlier only 44 per cent had favoured a greater role for religious beliefs, and 8 per cent had opposed it). In the same survey, 47 per cent thought religion could be of benefit to their own lives, with only 3 per cent taking a different view. ${ }^{17}$ What, more generally, could religion offer a member of contemporary Russian society? For just over half ( 52 per cent) it was an appreciation of 'moral norms', and for another 21 per cent (including many atheists) it was an 'understanding of the meaning of life'. A further 9 per cent thought it might help to 'save souls' (there were again some atheists who shared this view); and others thought religion could help to relieve their daily 
anxieties or reconcile them to the prospect of death. ${ }^{18}$ More generally, nearly threequarters were strongly or very strongly of the view that they would 'like [their] life to have more of a spiritual content'. 19

There was also a broad measure of support, in the late communist years, for a more prominent role for the church in public life. In a 1989 all-union survey, 90 per cent were in favour of the churches taking on a greater role in charitable work; 87 per cent thought the churches should be more directly involved in disaster relief; and very substantial majorities thought the churches should be involved in the conciliation of inter-ethnic disputes ( 77 per cent) and in the mass media (62 per cent). ${ }^{20}$ There was general agreement, in a 1990 survey, that the church still had 'too few rights and freedoms'. There was overwhelming agreement, for a start, that religious literature should be more widely available ( 83 per cent), and there was substantial agreement ( 56 per cent in favour, 21 per cent against) that children should be able to receive a religious education provided parents had given their approval. Just over two-thirds ( 68 per cent) thought it was 'important' that religious leaders took part in the work of the elected soviets, and just over half ( 52 per cent) thought it 'essential' for religious organisations to become more prominently involved in public life, with a further 33 per cent regarding it as 'acceptable' (only 4 per cent were opposed to the proposition). ${ }^{21}$ About half of the Soviet population, by the late 1980s, regarded themselves as religious believers; Christians were the most numerous, with about 41 per cent of the total population, followed by Muslims with 5 per cent and adherents of other faiths with 1.5 per cent. A much higher proportion (68 per cent) had themselves been christened. ${ }^{22}$

The position of religious belief in late communist Russia was nonethless a complex and contradictory one. Levels of identification with the Orthodox Church, for a start, were considerably higher (at 46 per cent) than the proportion of the population that reported a belief in God. There were many more who had no religious feelings or were even atheists but who believed religion made a positive contribution to national life. In a 1990 Russian survey, for example, 61 per cent of nonbelievers were sure religion was needed for national self-consciousness, 31 per cent thought it was needed for state administration, and 27 per cent for democracy. ${ }^{23}$ There were substantial variations, as in other societies, between religious affiliation, belief in God and regular worship; and many more were ready to support a greater role for religion in the wider society than in their own lives and in those of their priests and acquaintances. ${ }^{24}$ Asked to name the most outstanding personality that had ever lived on earth, in a survey conducted in August 1992, 13 per cent of those who identified themselves as Christians opted for Lenin; Jesus Christ himself came a poor sixth in the survey, after Peter the Great, Sakharov, Pushkin and Tolstoy, and with the same rating ( 2 per cent) as Stalin. ${ }^{25}$ As for a life after death, Muscovites were more inclined to believe that it existed ( 44 per cent) than to take the opposite view ( 31 per cent); but of those that responded, 21 per cent thought they would go to heaven, 20 per cent thought they would go to hell and the remaining 59 per cent had no idea. ${ }^{26}$

Religious affiliations were themselves undergoing a substantial change in the late communist period. The 'religious boom', for a start, appeared to be subsiding, with a slight fall in the number of reported believers in the largest cities in which the movement of the 'spiritual pendulum' had previously been most marked. ${ }^{27}$ There was a slight fall, similarly, in the proportion who were ready to agree that religion 'played an important part' in their life. This left levels of religiosity at a higher level than before, but lower than comparable levels in other European countries (just 46 per cent, in a 1991 survey, 'never doubted' the existence of God, compared with 87 per cent in the United States and 58 per cent in Britain ${ }^{28}$ ). There was a considerable decline, more 
particularly, in support for the Orthodox Church: partly in response to the reports that were emerging of its close relationship with the Soviet government and the KGB, but partly also because of a more general movement towards other religious beliefs including Catholicism or (much more commonly) towards a nondenominational identification with 'Christianity in general'. ${ }^{29}$

An interest in the spiritual, moreover, was by no means confined to orthodox religions. ${ }^{30}$ The 1991 survey, already cited, suggested that an interest in the supernatural could - for the youngest age groups - exceed a belief in God or an agnostic or atheist position. Respondents of this kind were 'keenly interested' in Eastern religions, spritualism, parapsychology, UFOs and much more. Levels of belief in the paranormal were particularly high among the better educated: of those with university degrees 73 per cent believed in telepathy and 42 per cent in astrology, and for 27 per cent Oriental wisdom played an 'important part' in their lives. Only 15 per cent, by contrast, believed in God. The result was a category of people who were 'believers and nonbelievers at the same time, combining their formal membership in a Christian church with rapidly changing passions for Hasidism, the Bhagavad Gita, Buddhism, or anything else'. Marxism might have lost its meaning, and Orthodox Christianity had ossified, but Russia, it appeared, was 'ahead of the western world and of the whole planet' in the 'amorphous and eclectic' character of its public beliefs. In terms of politics, atheists were more likely to identify with 'socialism' than believers, agnostics or spiritualists; believers, however, were more positively disposed towards 'Marxism' and 'socialism' than agnostics or spiritualists, and they were more predisposed towards order and firm authority than all other groups. Spiritualists, by contrast, were the most likely to reject the October revolution and to support liberal reforms. ${ }^{31}$

Alternative ideologies, including supernatural ones, had certainly become well established by the late communist period. The main television services had begun to incorporate an 'astrological forecast' for the following day, and many newspapers including the popular trade union daily Trud - contained a regular column of advice on such matters. Bookstalls in underground stations reflected the same emphases: there were Nostradamus and Madame Blavatskaya, L. Ron Hubbard and the Bhagavad Gita, Sigmund Freud and the Tibetan Book of the Dead, as well as Emmanuelle, the Marquis de Sade and How to Become a Millionaire in the CIS. A large majority (64 per cent), according to the polls, were pleased that newspapers and journals had begun to give a greater degree of attention to mysticism, unorthodox medicine, extrasensory perception and matters of this kind. More than half thought those with a special gift could foretell the future (50 per cent) and cure the sick by means of hypnosis ( 63 per cent) or television psychotherapy ( 57 per cent). There were many more believers than disbelievers in omens, telepathy, horoscopes or even flying saucers; and substantial minorities believed in witchcraft ( 35 per cent) or communication with the dead (11 per cent). ${ }^{32}$ If this was a Christian society it was also one that incorporated many older and more diverse beliefs and values.

\section{Forms of Religious Commitment}

On the eve of the collapse of communism, then, three broad trends were apparent in Russian approaches to religious beliefs and practices. First, widespread religious feelings existed among the general population, and these feelings would appear to have been in evidence for some considerable time, despite the many official efforts of the state to suppress them. ${ }^{33}$ Religious sentiments were reflected not only in a general sense of religiosity, but also in behavioural practices such as church attendance and the 
large proportion of children that were baptised. Secondly, the official churches enjoyed considerable popular support for their role in society, again in spite of the official policy that had - at least until the late $1980 \mathrm{~s}$ - been adopted towards them. Finally, as in many western societies, the 1970 s and 1980s witnessed a large increase in support for alternative religions and sects, many of them demanding a high level of commitment from their members. Unlike the pattern in western societies, however, this growth does not appear to have taken place at the expense of the established religions. ${ }^{34}$

The international research on the sociology of religion has emphasised three major dimensions to religious commitment, all of which have different social roots and different consequences for social and political behaviour. ${ }^{35}$ The first and most obvious is religious affiliation, reflected in whether or not a person is a church member. Membership is moulded at least in part by parental socialisation, mainly on the maternal side, ${ }^{36}$ and it has a variety of consequences for social and political behaviour since people interact together within their chosen denominational groups. The second dimension of commitment is religious behaviour or church attendance. In contrast to affiliation, behaviour is correlated with socioeconomic status; the higher the status, the more likely it is that the person will attend church. Like affiliation, there are a variety of social and political consequences which stem primarily from social interaction. Thirdly, religious belief is concerned with the fundamental tenets of religion; although the roots of religious belief are complex, they are most often associated with sociopersonality factors; they have few, if any, consequences for politics.

To date, no comprehensive Russian opinion survey has been conducted which deals with all three of these dimensions of religious commitment in detail, and the limited inquiries that have been conducted through surveys have involved either a single question or a small group of questions. To ascertain the extent of religious commitment in postcommunist Russia we use two national opinion surveys, conducted in February and December 1992 respectively (for further details see the Appendix). Both the surveys included a question on the frequency of church attendance, but only the February survey contained a question on affiliation, and only the December survey included a question on belief. This necessarily limits the analyses that can be undertaken, particularly with regard to the social bases and political consequences of these dimensions; it does, however, have the advantage of enabling us to check the validity

Table 2. Religious affiliation and religious belief in Russiaa

\begin{tabular}{lrlr}
\hline & Feb. 1992 & & Dec. 1992 \\
\hline Religious affiliation $^{b}$ & 51 & Belief in God & 44 \\
No affiliation & 21 & No belief & 28 \\
Difficult to answer & 28 & Difficult to answer & 28 \\
$\quad \begin{array}{l}\text { Total } \\
(n)\end{array}$ & 100 & Total & 100 \\
& $(2,095)$ & $(n)$ & $(1,481)$ \\
\hline
\end{tabular}

\footnotetext{
a Excludes 11 respondents in February 1992 and 28 respondents in December 1992 who gave ambiguous responses or who refused to answer.

b Namely, Orthodox (43 per cent), believer but unaffiliated (6 per cent), Muslim (2 per cent), and others (1 per cent).

Source: February 1992 Russian State-Market Survey $(n=2,106)$; December 1992 Political Parties of Russia Survey $(n=1,509)$
} 
of the church attendance measure, asked in both surveys within the same calendar year.

The February 1992 survey indicates that just over half of the population report some form of religious affiliation (Table 2). However, this figure hides a large proportion 28 per cent - who said that the question was 'difficult to answer'. About one in every five Russians has no religious affiliation, a level of secularisation that is broadly in line with that found in contemporary western societies. ${ }^{37}$ The second survey shows that slightly fewer respondents, 44 per cent, believe in God; this figure is almost exactly the same as that found in a survey conducted in September 1991, already quoted, which estimated religious believers to be 41 per cent of the population. ${ }^{38}$ Once again a significant proportion of the survey respondents found the question difficult to answer. This group is easily identifiable as those who are undecided about their belief; less easy to interpret are those who respond 'difficult to answer' to the question about affiliation, since a person must - at least in principle - be a member of a church or otherwise.

There are several possible explanations for this apparent anomaly in responses to the affiliation question. The first is the ambiguous nature of church membership, particularly in Russian circumstances. For many of the established denominations, such as the Roman Catholic Church, membership is often interpreted as having been baptised or confirmed in childhood, rather than formal membership in a local church. The Protestant churches, like the Russian Orthodox Church, adopt a more formal definition or membership involving enrolment in a local group and at least some frequency of attendance at religious ceremonies and gatherings. Given these differing definitions, it is perhaps not surprising that some respondents are confused by the concept of church membership. A second explanation is that the survey respondents interpreted the question about membership at least partially in terms of belief. The relationship between belief and affiliation in the two surveys and church attendance gives some support to this hypothesis; in each survey the 'difficult to answer' respondents are the most infrequent church attenders, whereas attendance and affiliation are less strongly correlated in Western Europe and the societies that are derived from it. ${ }^{39}$ This suggests that Russians regard affiliation and belief as very similar concepts. This may in turn be a legacy of the communist suppression of religion; since various formal and informal sanctions existed to discourage religious

Table 3. Frequency of church attendance ${ }^{a}$

\begin{tabular}{lrrrrrr}
\hline & \multicolumn{2}{c}{ Feb. 1992 } & & \multicolumn{2}{c}{ Dec. 1992 } \\
\cline { 2 - 3 } \cline { 5 - 6 } & All & Attenders only & & All & Attenders only \\
\hline Nonattenders & 45 & - & & 49 & - \\
Once a week or more & 1 & 2 & & 1 & 2 \\
Once a month or more & 3 & 6 & & 4 & 7 \\
Few times a year & 13 & 23 & & 11 & 21 \\
Very rarely & 38 & 69 & & 36 & 70 \\
& Total & 100 & 100 & & 101 & 100 \\
& $(n)$ & $(2,106)$ & $(1,161)$ & & $(1,485)$ & $(760)$ \\
\hline
\end{tabular}

a The December 1992 survey had six categories of attendance, which were aggregated as follows: once a week or more (nearly every day, several times a week); once a month or more (several times a month); few times a year (not every month); very rarely (only on certain days, difficult to answer). Source: as for Table 2. 
involvement, affiliation was often tantamount to belief (representing a positive commitment), whereas in western pluralist societies the two are less strongly associated. ${ }^{40}$

Just over half of Russians attend church, according to our survey, although no more than one in five do so on an infrequent or more frequent basis. Table 3 indicates that, judged across the two surveys, those who attend church once a month or more account for no more than 5 per cent of the total population. Between 11 and 13 per cent say that they attend church several times a year, attendances that would normally coincide with major religious celebrations. Finally, just over one-third report very rare attendance, most of which would be in the form of baptism, funerals and marriages. These are levels of church attendance that are generally below those found in most western countries, and given the widespread nature of religious affiliation and belief in Russia may again reflect the consequences of the communist suppression of religious practices. The results also vary little between the two surveys, suggesting that there has been no change in levels of church attendance between the two surveys, but perhaps more importantly confirming that both surveys are reasonably accurate in the levels of attendance that they report.

The two surveys, taken together, suggest that levels of religious affiliation and belief in Russia are very similar to the levels found in western societies. Moreover, there is some evidence to indicate that many conceive of affiliation and belief in the same way. By contrast, levels of church attendance are lower than would be found in the West, particularly when levels of belief and affiliation are taken into account. The results suggest that the Soviet authorities' sustained attempt to suppress religious beliefs and practices, while they failed to eliminate those beliefs or an informal commitment to a church, did have an impact in reducing levels of church attendance - an overt and public act which is comparatively easy to monitor and control. Although these policies began to be liberalised with the accession of Gorbachev to party office in March 1985 , it was not until October 1990 (as we have seen) that religious rights were guaranteed under the law.

\section{The Social Bases and Political Consequences of Religion}

The three major dimensions of religious commitment that have been identified in international studies have been shown to have distinctive roots within the societies in question. These social correlates can be traced not only to Marx, who viewed religion in terms of social class, but also to Durkheim and Weber, both on whom viewed religion as one of the fundamental bases of the prevailing social order. Religious affiliation is the easiest to categorise, since it is associated with higher social status, reflecting established social patterns of voluntary group membership. This may, of course, be complicated by the level of commitment demanded by a particular church, but in general the association has been shown to hold across a wide range of countries. Moreover, in recent years the denial of religious affiliation has been most closely associated with the young and with those who have had higher education. Participation in church attendance is usually associated with gender, age and socioeconomic status: women are more diligent attenders than men, as are older people and those in higher status positions. Finally, belief in the supernatural dimension of religion is usually associated with lower educational attainments, with women, and with older people. ${ }^{41}$

To evaluate the social bases of religion in Russia we use a range of variables measuring various social influences to predict affiliation, church attendance, and religious belief (Table 4). The analyses use ordinary least squares regression 
techniques, which control for a wide range of potentially confounding factors. The equations in Table 4 show two figures, partial regression coefficients (bs) and standardised regression coefficients (betas). The partial coefficients reflect the importance of a particular variable in predicting the dimension of religious commitments in question. For example, in the first equation in Table 4, the coefficient of -0.19 suggests that a man is 19 per cent less likely to report affiliation with a church than a woman, net of all the other factors controlled for in the model. The standardised coefficients show the relative weight of the variables in the particular equation. For example, in the first equation, gender (with a beta of -0.24 ) is about eight times more important in predicting affilation than age (with a beta of 0.03 ), again net of other factors.

Table 4. The social bases of religious commitmenta

\begin{tabular}{|c|c|c|c|c|c|c|c|c|}
\hline & \multicolumn{4}{|c|}{ February 1992} & \multicolumn{4}{|c|}{ December 1992} \\
\hline & \multicolumn{2}{|c|}{ Affiliation } & \multicolumn{2}{|c|}{ Attendance } & \multicolumn{2}{|c|}{ Belief } & \multicolumn{2}{|c|}{ Attendance } \\
\hline & $b$ & beta & $b$ & beta & $b$ & beta & b & beta \\
\hline \multicolumn{9}{|l|}{ Background } \\
\hline Gender & $-0.19 * *$ & $-0.24^{* *}$ & $-0.07^{* *}$ & $-0.15^{* *}$ & $-0.24^{* *}$ & $-0.29 * *$ & $-0.08^{* *}$ & $-0.14^{* *}$ \\
\hline Age & 0.00 & 0.03 & $0.01^{* *}$ & $0.10^{* *}$ & -0.00 & -0.01 & 0.00 & 0.06 \\
\hline Russian & $-0.10^{* *}$ & $-0.07^{* *}$ & -0.04 & -0.05 & -0.04 & -0.03 & 0.00 & 0.00 \\
\hline Lives in European Russia & 0.03 & 0.04 & $0.05^{* *}$ & $0.10^{* *}$ & $0.13^{* *}$ & $0.15^{* *}$ & 0.02 & 0.04 \\
\hline \multicolumn{9}{|l|}{ Socioeconomic status } \\
\hline \multicolumn{9}{|l|}{ Education (elementary) } \\
\hline Technical secondary & $-0.07^{*}$ & $-0.05^{*}$ & $-0.08 * *$ & $-0.11^{* *}$ & $-0.12^{* *}$ & $-0.11^{* *}$ & -0.05 & -0.07 \\
\hline Technical college & $-0.09 * *$ & $-0.10^{* *}$ & -0.03 & -0.06 & $-0.11 * *$ & $-0.13^{* *}$ & $-0.07^{*}$ & $-0.13^{*}$ \\
\hline Higher & $-0.12^{* *}$ & $-0.14^{* *}$ & -0.02 & -0.04 & $-0.18^{* *}$ & $-0.22^{* *}$ & -0.02 & -0.03 \\
\hline Income & 0.00 & 0.00 & 0.00 & 0.04 & -0.00 & -0.01 & 0.00 & 0.00 \\
\hline Living standards & 0.05 & 0.03 & 0.04 & 0.05 & 0.03 & 0.01 & $0.13^{*}$ & $0.10^{* *}$ \\
\hline Previous CPSU member & $-0.12^{* *}$ & $-0.11^{* *}$ & -0.05 & $-0.07^{*}$ & $-0.07^{* *}$ & $-0.07^{* *}$ & -0.03 & 0.04 \\
\hline Constant & 0.84 & & 0.10 & & 0.79 & & 0.21 & \\
\hline Adj. $R$-squared & 0.09 & & 0.06 & & 0.14 & & 0.03 & \\
\hline$(W)$ & $(2,033)$ & & $(1,087)$ & & $(1,481)$ & & $(760)$ & \\
\hline
\end{tabular}

* * Statistically significant at $P<0.01,{ }^{*} P<0.05$, both two-tailed.

a OLS regression equations predicting the probability of support for religious affiliation, church attendance, and belief in God. See Appendix Table for details of variables and scoring.

The results suggest that there is a high level of consistency in the social correlates across all three dimensions, in both surveys. The directions of the variables that are statistically significant are consistent, although their magnitudes vary. This suggests, once again, that the dimensions of commitment are less differentiated in Russia than in western societies. The predominant effects come from gender and education. As in other societies, women are significantly more likely to be religious than men; the impact varies from belief, where women are 24 per cent more likely to believe in God than men, net of other factors, to 7 and 8 per cent, respectively, for church attendance 
in the February and December surveys. These effects are larger than those found in the liberal democracies, and have been confirmed by other studies. ${ }^{42}$ Higher educational attainments are likely to produce lower levels of commitment; for example, someone who has had higher education is 18 per cent less likely to believe in God, compared to someone with elementary education, other things being equal. Other aspects of socioeconomic status have little or no impact, with the exeception of better selfperceived living standards, which increases the probability of church attendance in the December 1992 survey.

Among the other factors that are important, ethnic Russians are less likely to have a religious affiliation than others, but this effect does not reach statistical significance for either of the other three equations. Those living in European Russia, as opposed to Asiatic Russia, are likely to attend more frequently (in the February survey) and to be religious believers. Finally, former CPSU members are less likely to be religious than nonmembers, although given the CPSU's formal policy on religion it is perhaps surprising that the effects are not larger. For example, in the first equation, former CPSU members are 12 per cent less likely to be affiliated to a church than nonmembers, an effect which is similar to attending technical college but less than half as important as gender. The only major exception to the expected patterns is age, which has no significance in three of the equations, and is significant only for church attendance in the February 1992 survey, in the expected direction. This contradicts all of the research on the sociology of religion, ${ }^{43}$ although it is largely confirmed by other Russian survey research, which indicates that age and religion are, at best, only modestly associated. ${ }^{44}$ The most likely explanation for this would appear to be, once again, official policies towards religion: the elderly, otherwise more likely to attend religious services, became adults at a time when practices of this kind were strongly discouraged; younger citizens, by contrast, are more likely to have experienced the relative liberalisation of the Khruschchev years and afterwards.

\section{The Politics of Religion in Postcommunist Russia}

It remains to examine the political consequences of religion in postcommunist Russia. Religion has a range of consequences for political behaviour in modern societies, partly through the historical consequences of religious divisions and cleavages that existed in earlier centuries, but partly also as a consequence of group memberships and shared beliefs and values. ${ }^{45}$ In communist Russia, religion was forced to withdraw from any public role, although a small minority of religious activists become highly politicised as a result of their harsh treatment by the regime, particularly under Brezhnev (the churches, as institutions, were less harshly treated). In practice, however, most of those harbouring religious beliefs or values kept them to themselves, and the extent to which these beliefs influenced their political views was likely to be, at best, limited. The collapse of communism, the removal of barriers to religious expression and moves to establish more democratic institutions have all created the preconditions under which religion could have a significant role in shaping political behaviour in postcommunist Russia.

To estimate the extent to which the three dimensions of religious commitment influence political attitudes and political behaviour we examine their association with a range of political opinions, and with voting in the 1991 presidential election. Table 5 identifies nine political attitudes covering foreign affairs and defence, economic attitudes and evaluations of different political systems, and correlates these opinions with belief in God and church attendance using the December 1992 survey. The 
association between religion and political opinion is decidedly modest, although there are several statistically significant effects. Those who believe in God are more likely to want Russia to remain as a great power, as well as to favour a national-patriotic political system - basic nationalist goals. They are also more likely to support the principle of private property, and to be hostile to communism. Frequent church attenders are also more likely to support private property and to be anticommunist, but again the effects are noticeably weak. Whatever factors serve to shape political opinions in Russia, religion has a comparately minor role.

Table 5. The influence of religious commitment on political attitudes (correlations)

\begin{tabular}{lcc}
\hline & \multicolumn{2}{c}{ (Zero-order correlations) } \\
& Belief in God & Church attendance \\
Foreign affairs and defence & & \\
Russia must be great power & $0.05^{*}$ & 0.04 \\
Defence capacity better & -0.04 & 0.02 \\
Supports national self-determination & 0.02 & 0.03 \\
& & \\
Economic attitudes & $0.05^{*}$ & $0.05^{*}$ \\
Private property necessary for development & -0.01 & 0.03 \\
Gap between rich and poor normal & 0.00 & 0.03 \\
Admires new rich & & \\
& & 0.00 \\
Evaluations of political systems & -0.01 & $-0.06 *$ \\
Democracy & $-0.10^{*}$ & 0.03 \\
Communism & $0.05^{*}$ & \\
National-patriotic & & \\
\hline
\end{tabular}

* Statistically significant at $P<0.05$ or better, two-tailed.

Source: December 1992 Political Parties of Russia Survey ( $n=1,509)$.

The influence of religion on voting in the 1991 presidential election also appears to have been comparatively modest, based on respondents' recall of how they cast their ballots (Table 6). Studies of non-voting have shown that abstention is associated partly with a low sense of political efficacy, which is reflected in low levels of group membership. ${ }^{46}$ We would therefore expect those who are affiliated with a church and are regular attenders to be less likely to have abstained in the election. This hypothesis is confirmed by the results in Table 6, though the relationships are modest; those who abstained were more likely not to have a religious affiliation (19 per cent, as against 21 per cent of voters). In the December 1992 survey, 18 per cent of non-voters attended church several times a year or more, compared with 32 per cent of voters. There are also some variations in the support given to the candidates among the religious groups. Those more likely to have attracted the support of the religious include Bakatin and Makashov, while Zhirinovsky and Ryzhkov were more likely to gain support from those with fewer religious inclinations. Once again, however, the magnitude of the effects (and to some extent their consistency across the four indicators) is decidedly modest. Yel'tsin, the winner of the election, appears to have gained no advantage or disadvantage from the religious beliefs and practices of Russian voters. 
Table 6. Religion and the 1991 presidential election vote ${ }^{\mathrm{a}}$

\begin{tabular}{|c|c|c|c|c|c|c|c|c|}
\hline & (All) & Bakatin & Yel'tsin & Zhirinovsky & Makashov & Ryzhkov & Tuleyev & $\begin{array}{l}\text { Did not } \\
\text { vote }\end{array}$ \\
\hline \multicolumn{9}{|l|}{ Affiliation } \\
\hline Affiliation & (51) & 53 & 52 & 45 & 61 & 54 & 57 & 48 \\
\hline No affiliation & (21) & 22 & 20 & 22 & 23 & 29 & 20 & 19 \\
\hline Difficult to answer & (28) & 25 & 28 & 33 & 16 & 17 & 23 & 33 \\
\hline \multicolumn{9}{|l|}{ Belief } \\
\hline Believer & (44) & 40 & 46 & 48 & 37 & 30 & 44 & 46 \\
\hline Non-believer & (28) & 32 & 25 & 28 & 36 & 45 & 27 & 22 \\
\hline Difficult to answer & (28) & 28 & 28 & 24 & 27 & 25 & 28 & 32 \\
\hline \multicolumn{9}{|c|}{ Attendance (February 1992) } \\
\hline Once a week or more & (2) & 0 & 2 & 0 & 0 & 2 & 0 & 2 \\
\hline Once a month or more & (6) & 14 & 5 & 5 & 6 & 11 & 0 & 7 \\
\hline Few times a year & (23) & 32 & 23 & 15 & 24 & 34 & 16 & 19 \\
\hline Very rarely & (69) & 54 & 70 & 80 & 70 & 53 & 84 & 72 \\
\hline \multicolumn{9}{|c|}{ Attendance (December 1992) } \\
\hline Once a week or more & (2) & 3 & 3 & 0 & 0 & 3 & 2 & 0 \\
\hline Once a monthor more & (7) & 14 & 8 & 8 & 0 & 5 & 4 & 3 \\
\hline Few times a year & (21) & 29 & 21 & 31 & 23 & 25 & 22 & 15 \\
\hline Very rarely & (70) & 54 & 68 & 61 & 77 & 67 & 72 & 82 \\
\hline
\end{tabular}

Figures may not sum due to rounding.

Source: as for Table 2.

\section{Conclusion}

Earlier studies of the political implications of Russian religion have drawn attention to its authoritarian potential. A survey conducted in September 1991, for instance, found that believers were 'more conservative on every issue', more supportive of the existing order and of political movements at either end of the spectrum that promised to restore it, and generally 'distrustful of change'. Believers, in this survey, did not necessarily support a Marxist-Leninist social order, nor were they more positive than nonbelievers towards socialism or Lenin. They were, however, more strongly supportive of the existing social order, and they were much more favourably oriented towards two rather different symbols of stability - Stalin and the tsar. In addition, believers were less tolerant of political diversity, and more likely to agree with authoritarian solutions to social problems like the treatment of AIDS victims or the banning of 'harmful' literature; they were less favourable towards multiparty politics, and more likely to agree that changes were taking place too quickly. ${ }^{47}$ On this basis, and given the more prominent public role that the churches have assumed and the weakness of political parties as a means of articulating a public view, Russian believers might be expected to represent a force of some importance and one that would tend to influence the society towards a greater degree of public order and ideological uniformity, if not MarxismLeninism as such. 
The surveys that we have considered in this paper, both of them comparable in scope with these earlier findings but conducted after the end of communist rule, suggest that a conclusion of this kind is premature and almost certainly misleading. The rapid increase in the proportion of society declaring a religious belief, as we have seen, had slowed down considerably in the early 1990s. By the spring of 1991 levels of religiosity had increased considerably but were still below the levels reported in Western Europe, and still more so the United States. On the evidence of our two 1992 surveys, moreover, levels of religious attendance are considerably below the levels that are typically reported in the pluralist societies of the West. And relatively high proportions are unsure of their belief, and of their religious affiliation: a response that may in part reflect the tradition of Russian Orthodoxy, based as it is upon a large and nebulous community of believers rather than a formalised pattern of individual membership, clear statements of doctrine and sometimes direct financial responsibility. Equally, it may reflect the significant increase in the numbers of 'Christians in general' without a denominational commitment.

Our findings also suggest a rather weaker association between religiosity and political beliefs and actions. For instance, we found at most a modest association between a range of political attitudes and a declared belief in God and church attendance. There were associations, but relatively weak ones, between religious beliefs and a range of broadly 'nationalist' opinions; there were again at best modest associations between religious beliefs and attitudes towards social and economic change, and towards various types of political systems. There was also a very limited association between religious belief and political affiliation, expressed in the form of the Russian presidential elections of June 1991. Believers were somewhat more likely to vote than nonbelievers, but the effects were relatively modest as compared with societies elsewhere, and religious affiliation made little direct contribution to voting choice.

It may seem surprising that religious belief does not appear to have a more direct association with public life in a postcommunist Russia in which the rights of believers, for the first time, are firmly protected by law, and religious leaders are more prominent in politics. One reason may be the absence of an established tradition of religious involvement in public affairs over the past seventy years or more, and the weakness of that tradition in the prerevolutionary period. The failure of at least some members of the hierarchy to articulate an independent and specifically Christian position after 1917, and the evidence of corruption and even KGB infiltration within its ranks, weakened the moral authority of the church leadership even further. The churches have equally had little opportunity to organise themselves as a distinctive voice in public life since it became possible to do so, and they had no organised presence in party politics that they could simply inherit after the end of communist rule (the position was very different in some of the East European countries). Finally, the particular legacy of the CPSU may have placed the churches in some difficulty. As institutions and communities of believers that were broadly supportive of the established order, the churches found themselves - in early postcommunist Russia - in the same position as a Communist Party that also supported the main features of the Soviet system, but that was at the same time a party that had sought for more than 70 years to eliminate religion from public life and one with which the churches could scarcely form a direct association. It may be some time, in these circumstances, before a distinctively Christian perspective is successfully articulated within a society that is still powerfully influenced by its recent communist and sometimes by its remoter prerevolutionary past. 


\section{Appendix: Data and Methods}

\section{Data}

The analyses rely on two opinion surveys conducted in urban areas in Russia in 1992. The 1992 Russia Between State and Market Survey was collected by the Public Opinion Foundation in January and February 1992. The sample was based on the urban population aged 16 years and over resident in the Russian Republic. The survey was conducted using a personal interview; the effective response rate was 82.9 per cent. The total sample size was 2,106 ; the analyses presented here are restricted to those aged 18 years and over $(n=2,033)$. The 1992 Political Parties of Russia Survey was conducted in December 1992 by the Institute of Applied Politics using a personal interview. The sample was based on the urban population aged 18 years and over resident in the Russian Republic. Neither the collectors of the data nor the sponsors are responsible for the analyses and interpretations in this article.

\section{Methods}

The analyses rely on cross-tabulation and ordinary least squares regression techniques. The latter method assumes that the relationships between the variables are linear and additive. The variables used in the analyses are scored as follows. Religious affiliation and belief are scored one if the person had an affiliation or a belief, 0.5 if they were unsure or undecided, and zero if they did not. Church attendance is scored as an ordinal variable, from a low of zero (never attends) to a high of one (attends once a week or more). All the independent variables used in Table 4 are scored as zero/one dummy variables, with the exception of age (scored in single years) and family income (hundreds of roubles per month).

\section{Notes and References}

1 For a recent and comprehensive survey see Sabrina Petra Ramet (ed.), Religious Policy in the Soviet Union (Cambridge University Press, Cambridge, 1993).

2 For Gorbachev's baptism see Izvestiya TsK KPSS, no. 8, 1989, p. 66; for his mother's church attendance see, for instance, Michael Bourdeaux, Gorbachev, Glasnost and the Gospel (Hodder and Stoughton, London, 1990), p. 24.

3 Izvestiya, 9 April 1988, p. 3.

4 Pravda, 30 April 1988, pp. 1-2.

5 ibid, 16 March 1990, p. 6.

6 See Vedomosti S"ezda narodnykh deputatov SSSR $i$ Verkhovnogo Soveta SSSR, no. 11, 1990 , art. 164.

7 For the text see ibid., no. 41, 1990, art. 813; for a discussion and translation see Giovanni Codevilla, 'Commentary on the new Soviet law on freedom of conscience and religious organisations', Religion in Communist Lands, vol. 19, nos. 1-2 (Summer 1991), pp. 119-45.

8 See Vedomosti..., no. 37, 1991, art. 1083.

9 Gosudarstvo i pravo, no. 4, 1992, pp. 4-8, and (for the constitutional amendments) Vedomosti S"ezda narodnykh deputatov Rossiiskoi Federatsii $i$ Verkhovnogo Soveta Rossiiskoi Federatsii, no. 20, 1992, art. 1084.

10 Izvestiya, 10 July 1991 , p. 1.

1 For a discussion of the establishment and objectives of these parties see V. N. Berezovsky et al. (eds.), Rossiya: partii, assotsiatsii, soyuzy, kluby, vol. 1, part 1 (RAU Press, Moscow, 1991), pp. 22-3. On the Russian Christian Democratic Movement more particularly see Richard Sakwa, 'Christian democracy in Russia', Religion, State and Society, vol. 20, no. 
2 (1992), pp. 135-68, and the 'Documentary appendix', ibid., pp. 169-200.

12 Pravda, 4 February 1991, p. 6.

13 For a more general discussion of the survey see Irina Boeva and Viacheslav Shironin, Russians between State and Market: the Generations Compared (Centre for the Study of Public Policy, University of Strathclyde, Glasgow, 1992).

14 S. B. Filatov and D. E. Furman, 'Religiya i politika v massovom soznanii', Sotsiologicheskiye issledovaniya, no. 7, 1992, pp. 3-12.

15 ibid., p. 3.

16 ibid., pp. 3-4.

17 Mir mnenii i mneniya o mire, no. 1, 1992, p. 7; for the 1989 results see Obshchestvennoye mneniye $v$ tsifrakh, no. 5 (October 1989), p. 11.

18 Mir mnenii i mneniya o mire, no. 1, 1992, p. 7.

$19 R F E / R L$ Research Report, vol. 1, no. 41 (16 October 1992), p. 65.

20 Obshchestvennoye mneniye $v$ tsifrakh, no. 5 (October 1989), pp. 12-13.

21 ibid., no. 12(19) (April 1990), pp. 7-9.

22 ibid., no. 2(9) (January 1990), p. 12.

23 Filatov and Furman, 'Religiya i politika....', pp. 4-5.

24 Obshchestvennoye mneniye v tsifrakh, no. 12(19) (April 1990), pp. 6-7.

25 Mir mnenii i mneyiya o mire, no. 12, 1992, p. 8.

26 Izvestiya, 19 October 1992, p. 3.

27 Filatov and Furman, 'Religiya i politika...', p. 5.

28 See The Pulse of Europe, Los Angeles Times-Mirror (Washington DC, mimeo, 1991).

29 Filatov and Furman, 'Religiya i politika...', pp. 5-6.

30 See Oxana Antic, 'The spread of modern cults in the USSR', in Ramet (ed.)., Religious Policy..., pp. 252-70.

31 Filatov and Furman, 'Religiya i politika...', pp. 5-12.

32 Obshchestvennoye mneniye $v$ tsifrakh, no. 10, 1990, pp. 6-7.

33 For a discussion of state religious policies in the USSR and elsewhere in the communist world see, for instance, Patrick Michel, Politics and Religion in Eastern Europe (Polity, Cambridge, 1991); Robert F. Millar and T. H. Rigby (eds.), Religion and Politics in Communist States (Australian National University, Canberra, 1986); and Ramet (ed.), Religious Policy...

34 See for instance Eileen Barker, New Religious Movements: a Practical Introduction (HMSO, London, 1989).

35 For reviews, see: Gerhard Lenski, The Religious Factor (Doubleday, New York: 1961), pp. 17-23; N. J. Demerath, Social Class and American Protestantism (Rand McNally, Chicago, 1965), pp. 10-14; Charles Y. Glock and Rodney Stark, American Piety: The Nature of Religious Commitment (University of California Press, Berkeley, 1968), pp. 16-18; and Michael Argyle and Benjamin Beit-Hallahmi, The Social Psychology of Religion (Routledge and Kegan Paul, London, 1975).

36 See, for example, Ian McAllister, 'Religious change and secularization: the transmission of religious values in Australia', Sociological Analysis, vol. 49 (1988), pp. $249-63$.

37 See Michael Hogan, 'Australian secularists: the disavowal of religious allegiance', Journal for the Scientific Study of Religion, vol. 18 (1979), pp. 390-404; and McAllister, 'Religious change and secularization ...'.

38 See Mark Rhodes, 'Religious believers in Russia', RFE/RL Research Report, vol. 1, no. 14 (3 April 1992), pp. 60-4.

39 See, for instance, Glock and Stark, American Piety...

40 A third possible explanation might be that respondents were afraid to give a definitive response to the affiliation question in the interview. However, this would appear unlikely, since the respondents had exhibited no similar qualms on other or more sensitive questions, such as past voting behaviour, past and present CPSU membership, and income and foreign currency dealings.

41 For reviews of these social factors see Lenski, The Religious Factor; Argyle and Beit- 
Hallahmi, The Social Psychology of Religion; Michael Hill, A Sociology of Religion (Heinemann, London, 1973); and Barbara Hargrove, The Sociology of Religion (AHM Publishing, Arlington IL, 1979), pp. 135ff.

42 For comparative data and explanations, see David de Vaus and Ian McAllister, 'Gender differences in religion: a review of the structural location theory', American Sociological Review, vol. 52 (1987), pp. 472-81. An assessment of the Russian evidence is provided in John Anderson, 'Out of the kitchen, out of the temple: religion, atheism and women in the Soviet Union', in Ramet, Religious Policy..., pp. 206-28.

43 See, for instance, Dan Blazer and Erdman Palmore, 'Religion and ageing in a longitudinal panel', Gerontologist, vol. 16 (1976), p. 84; C. Ray Wingrove and Jon Alston, 'A cohort analysis of church attendance, 1939-69', Social Forces, vol. 53 (1974), p. 330.

44 For example, a 1991 survey of residents in major cities found that 36 per cent of those aged 18-20 believed in God, compared with 39 per cent of those aged 60 or over. The range of difference was only 15 points. See Filatov and Furman, 'Religiya i politika...', p. 4, Rhodes, 'Religious believers ...', shows a large age variation, although it is still only in the region of 20 percentage points (p. 62).

45 See Michael Parenti, 'Political values and religious culture: Jews, Catholics and Protestants', Journal for the Scientific Study of Religion, vol. 6 (1967), pp. 259-69; Guy Michelate and Michael Simon, 'Religion, class and politics', Comparative Political Studies, vol. 10 (1977), pp. 159-86.

46 See Raymond E. Wolfinger and Steven J. Rosenstone, Who Votes? (Yale University Press, New Haven CT, 1980).

47 See Rhodes, 'Religious believers in Russia'. 